\title{
TWISTING THE KNIFE- DISCRIMINATION IN THE LAW
}

\author{
KAREN GuRneY*
}

[Of the many different variations that can occur in human sexual formation, transsexualism no doubt remains the least understood by the wider Australian community. As a consequence, the process of attaining human rights to legal status, privacy, dignity and freedom from discrimination for those who experience this unusual condition has been a slow and sometimes frustrating one. The article seeks to introduce the reader to some of the more recent developments in the international jurisprudence of transsexualism and the underlying medical evidence that has supported them. It also offers criticism of the belated attempt by the State of Victoria, with the Births, Deaths \& Marriages Registration (Amendment) Act 2004, to establish certain statutory rights in this regard. While the legislation was enacted with the stated and very laudable purpose of providing for the correction of birth records on the Register of Births of those people with transsexualism who have altered their phenotypic sex by hormonal medication and surgery, the article argues it has also served to remove other equally important rights already won and proposes that a final remedy will only be found, as on previous occasions, in the courts.]

\footnotetext{
* LLB Candidate, School of Law, Deakin University.
} 
This is the way the world ends

This is the way the world ends

This is the way the world ends

Not with a bang but a whimper.

- T S Elliot, The Hollow Men (1925)

\section{INTRODUCTION}

Sometimes it must seem that people who experience transsexualism, having been trampled to the bottom of the heap by nearly all other factions since time immemorial, are prepared to sit back like those "hollow men" and quietly accept their meagre lot from society, rather than be counted when it matters most. Nothing, however, is further from the truth, especially when it is a matter of human rights and discrimination against them that is enshrined in law.

On 1 June 2004, the Governor of Victoria gave Royal Assent to the Births, Deaths \& Marriages Registration (Amendment) Act 2004. ${ }^{1}$ It provided a mechanism enabling Victorian citizens living with transsexualism to correct their Birth Certificate details to reflect their contemporaneous circumstances and be regarded as members of their affirmed sex for all purposes of the laws of Victoria. It drew no public media comment. The passage of the legislation through both Houses of the Parliament was similarly unremarkable - a reflection, perhaps, of the standard of debate and the fact it was 16 years in the coming. ${ }^{2}$

The Explanatory Memorandum described the purpose of the Bill as amending the principal Act 'to provide for the recognition of the sex of persons who have undergone sex affirmation surgery'. ${ }^{3}$ While the amended Act certainly achieves this, it fails as a comprehensive human rights document for three important reasons: it treats people with transsexualism differently to others diagnosed with variations in

\footnotetext{
${ }^{1}$ Act No 29 of 2004.

${ }^{2}$ The Sex Reassignment Act 1988 (SA) came into operation on 15 November 1988. This was followed at various times by similar enactments in other States and the Territories, Victoria being the last to respond. ${ }^{3}$ Births, Deaths \& Marriages Registration (Amendment) Bill 2004, Explanatory Memorandum, Parliamentary Document Library, Parliament of Victoria.
} 
sexual formation; it fails to accord a compassionate outcome to those who cannot undergo major surgeries for valid medical reasons; and it requires the dissolution of any existing valid marriage the applicant is a party to.

This article seeks to put some "bang" back into human rights processes within the federation of democratic States that is Australia.

\section{TRANSSEXUALISM AS AN INTERSEX CONDITION}

Ever since Dr Magnus Hirschfeld first distinguished the transsexual condition from transvestism, there has been a tension within the medical and social science communities as to its true aetiology. The weight of argument is now very firmly on the side of those who conceive of it as a biological condition, rather than a psychological one, so much so that a biological basis is now accepted as a fact proven to the civil standard under Australia's common law. ${ }^{4}$

Dr Hirschfeld was both an endocrinologist and a sexologist. He rationalised that only a biological explanation could reveal the mystery of this strange phenomenon in which the individuals not only wished to live as members of the sex opposite to their phenotypic sex, they actually believed themselves to be of that opposite sex and were prepared to go to great lengths to be accepted as such. He decided to classify the disorder in the newly created intersex nosology, ${ }^{5}$ first describing it as "psychic transsexualism" in 1923 in a paper titled, 'Die intersexuelle Konstitution'. 6 Hirschfeld used this new term to distinguish neurological gynandromorphs (people with both male and female brain formation) from physiological hermaphrodites (people with both male and female reproductive characteristics), but without establishing a separate nosographical category. ${ }^{7}$ Significantly, he was involved in the early pioneering work using hormones and surgery to correct the bodies of transsexual people once it became apparent that what was in their minds could not be changed. ${ }^{8}$

\footnotetext{
${ }^{4}$ Re Kevin (validity of marriage of transsexual) [2001] Fam CA 1074, [270]-[272].

${ }^{5}$ Richard Goldschmidt, 'Intersexuality and the Endocrine Aspects of Sex' (1917) 1 Endocrinology 453456: Goldschmidt was a very important evolutionary theorist and the first modern user of "intersexual" as a nosographical terminology.

${ }^{6}$ Magnus Hirschfeld, 'Die intersexuelle Konstitution' (1923) 23 Jahrbuch für sexuelle Zwischenstufen 3. Le premier usage du terme "transsexuel psychique" ("seelischer Transsexualismus"), qu'il distingue de la "corporéité gynandromorphe" des hermaphrodites physiologiques, mais sans individualiser une catégorie nosographique. [Author's translation: Magnus Hirschfeld, 'The Intersexual Constitution' (1923) Yearbook for Sexual Intermediaries 3-27. The first usage of the term, "psychic transsexualism" ("seelischer Transsexualismus"), that which distinguishes the psychological gynandromorph from the physiological hermaphrodite, but without making an individual nosographical category...]

7 'Bibliographical work on the problems of sexual identity' in Gallimard, The Impossible Metamorphosis: Essay on Transsexualism and Personal Identity (2003).

${ }^{8}$ See, for example: Magnus Hirschfeld, Sexualpathologie. Sexual Zwischenstufen Vol 2 (1922) which contains the first testimony on the history of surgical treatment of people with transsexualism, including the cases of "Rudolph", who had a bilateral mastectomy and took the name of "Gilded" (Dorchen), and Felix Abraham who had a penectomy (Hirschfeld was one of the team who reoperated on him in 1930 to
} 
In 1949, Cauldwell, a psychiatrist and sexologist, published a series of papers that was widely published amongst his peers. ${ }^{9}$ In them, he described transsexualism as a delusion and a sexual deviance. His theory gained wide acceptance and set in place the double stigma of delusion and sexual deviance, underpinned by ignorant prejudice, that became the lot of those affected by the transsexual condition. It spawned theories about excessively gay males and ultimate transvestites in a flush of sensationalist media reports surrounding the outing of former GI, Christine Jorgenson, ${ }^{10}$ in 1953. In doing so, the media ignored entirely the $50 \%$ of people with transsexualism that was born with a female phenotype. It is salient to this discussion that Christine, in her autobiography, defined herself as ' ... an individual belonging to the highest degree of intersexuality; male organs in a female body.'

Despite the rise and rise of the psychologists, strong efforts were made to continue research into the somatic approach as the hormonal and surgical treatment of the condition became ever more common and successful. Foremost in these efforts was Dr Harry Benjamin, another endocrinologist who had followed the earlier work of Hirschfeld with great interest. Benjamin clearly distinguished between transvestism (psycho-somatic) and transsexualism (somato-psychic) and became more and more intrigued by the experiences of those affected by the latter. As early as 1953, he advocated a biological explanation to the syndrome, believing that the genetic and endocrine systems must provide a "fertile soil" for environmental influences. ${ }^{11} \mathrm{He}$ stated that:

...[I]f the soma is healthy and normal no severe case of transsexualism....is likely to develop in spite of all provocations. ${ }^{12}$

In his Magnum opus, 'The Transsexual Phenomenon', ${ }^{13}$ which was published in 1966, Benjamin defined transsexualism by the individual's belief they are a member of the sex opposite their phenotype and a concurrent overwhelming need for surgical reassignment. ${ }^{14}$

Dr Benjamin strongly supported the view that transsexualism was a form of intersex condition saying:

Intersexes exist, in body as well as in mind. I have seen too many transsexual patients to let their picture and their suffering be obscured by uninformed albeit honest opposition. ${ }^{15}$...Biologically minded authors are likely to consider...TSism as one of the "intersexual" phenomena but

construct a neo-vagina making Abraham the first recorded case of male transsexualism treated by surgery).

${ }^{9}$ David Cauldwell, 'Psychopathia Transsexualis' (1949) 16 Sexology 274

${ }^{10}$ Christine Jorgensen, Emergence: A Transsexual Autobiography (1967).

${ }^{11}$ Dave King, The Transvestite and the Transsexual: Public Categories and Private Identities (1993) 14.

${ }^{12}$ Harry Benjamin, 'Transvestism and Transsexualism' (1953) 5(2) Journal of Sex Research 13

${ }^{13}$ Harry Benjamin, The Transsexual Phenomenon (1966).

${ }^{14}$ Ibid 2.

15 Ibid 51. 
those are almost exclusively European scientists. American writers...reserve the term "intersexuality" exclusively for visible signs of disorders of sexual development, that is to say, for hermaphroditic and pseudo-hermaphroditic abnormalities. The Europeans, especially the Germans, use the term in a much wider sense. ${ }^{16} 17$

That "wider" sense, of course, is the true meaning of the term first given it by Hirschfeld all those years ago; the condition where both female and male characteristics are present in an individual. ${ }^{18}$

Gillies and Millard pioneered phalloplasty repairs for soldiers who had been damaged in the genital region during World War II. Subsequently applying their skills in the areas of intersex and transsexual surgeries, they wrote in 1957 that:

The physical sex picture does not always bear a fixed relation to the behaviour pattern shown by an individual. One or other hormone may determine an individual's male or female proclivities quite independently of the absence of some of the appropriate physical organs. It may be suggested, therefore, that the definition of hermaphroditism should not be confined to those rare individuals with proved testes and ovaries but extended to include all those with indefinite sex attitudes. ${ }^{19}$

In more recent years, a plethora of researchers have given credence to the remarkable insight of these early researchers by providing both empirical and anecdotal proof of the biological intersex nature of transsexualism. Their findings have since been used to inform the common law of Australia.

Professor Louis Gooren, an endocrinologist and Chair of the only Faculty of Transsexualism in the world, a part of the Free University of Amsterdam and its teaching hospital, presented the Closing Speech at the Council of Europe's 23rd Colloquy on European Law in $1993 .^{20}$ Explaining the complex process by which a developing foetus becomes either male or female. Professor Gooren said:

Except for the chromosomes, there is no distinguishable difference between a future boy and a girl in the first 6 weeks of development. After

\footnotetext{
${ }^{16}$ Ibid.

${ }^{17}$ For example, Helene Stourzh-Anderle, a Viennese physician, favoured a biological approach and regarded transsexualism as 'anchored in an inborn constitution' and therefore 'an intersexual manifestation that could be combined with infantile (subsexual) features': Sexuelle Konstitution (1955) Verlag f. Medizinische Wissenschaften, Wien-Bonn.

${ }^{18}$ See, for example, Stedman's Medical Dictionary (Illus Version) (24 $4^{\text {th }}$ ed, 1984): 'intersex" - the condition of having both male and female characteristics; being indeterminate between the sexes; Macquarie Dictionary ( $\left.2^{\text {nd }} \mathrm{ed}, 1992\right) 1858$ : 'An individual displaying characteristics of both the male and female sex of the species.'

${ }^{19} \mathrm{H}$ D Gillies and D R Millard, The Principles and Art of Plastic Surgery (1957) 370-1.

${ }^{20}$ LJG Gooren, 'Transsexualism, Medicine and the Law' (1993) The Council of Europe's 23rd Colloquy on European Law April 14-16, 1993 at <http://www.mermaids.freeuk.com/gooren01.html>
} 
the first 6 weeks, the indifferent gonad becomes a testis in the case of a 46, XY pattern, and an ovary in case of a 46, XX pattern. All the following steps in the differentiation process are dependent on the hormones produced by the testis before birth. The next step in the differentiation process is that of the formation of the internal genitalia. These are completely identical ducts in boys and girls. In the presence of testicular hormones produced by the boy foetus, one pair of ducts will become prostate and deferential duct, while the other pair goes into regression. In a girl foetus, the development is the contrary: there are no testicular hormones, so one pair does not develop; the other pair becomes the uterus and oviducts. A couple of weeks later, the external genitalia develop from a common principle. In the presence of testosterone, as is normal in a boy, the external genitalia become a penis and a scrotum. In girls there is no testosterone around, and the external genitalia develop into a vulva and vagina. $^{21}$

Professor Gooren then discussed some of the ways in which the sexual differentiation process may not proceed according to expectations, resulting in (intersex) infants with atypical genitalia and/or karyotypes. Turning to the predicament of transsexualism, he said:

It has always been assumed that the sexual differentiation was completed with the formation of the external genitalia. But it is NOT. Since the beginning of this century we have known that the brain, too, undergoes a sexual differentiation... It is likely from the available evidence that in transsexuals the pattern of sexual differentiation of the brain has not followed the pattern typical of that sex: in other words, the nature of the chromosomes, the gonadal and genital development are in contradiction with the brain sex; at least with the sexual self-image of which we assume the substrate to be in the brain...

For all these people who have had the misfortune to incur a sex error of the body in their development, solutions have to be found... experience teaches that being intersex makes a person subject to social abuse; such a person becomes a freak. The only option is a rehabilitation to one sex or the other. Rehabilitation does not pretend to be a cure. It is exactly what the word says: rehabilitation makes the best of a condition that cannot be corrected essentially and fundamentally...

Sex reassignment of transsexuals is a medical intervention on a sliding scale. It is not essentially different from procedures in other sex errors of the body. The same interventions including genital surgery are done in other cases of sex errors of the body. This brings me to the issue raised in some of the legal material I have been reading in this context: Can it really

${ }^{21}$ Ibid 5 . 
be done: Sex reassignment in transsexuals? In other words: is the feminisation of the body by hormones and the construction of a neo-vagina, a true authentic sex change or is it a construct, an artefact, a modification only of the body? My answer would be that it is as much a sex change as it is in other cases of intersex. Many of the intersex cases will have contradictions between the variables, the criteria of sex ...

There can be no psychomedical ground not to treat these people respectfully; we must provide them with reassignment treatment which meets their needs. In the cases of intersex, and this is particularly true of transsexualism, medical treatment does not bring resurrection from one's ashes; it is not a cure. It is not a completely new start; it is a rehabilitation process. We must accept the given fact of sex errors of the body and continue from there. We must create the conditions for successful rehabilitation to the male or female sex as much in cases of transsexualism as in other cases of intersex subject. ${ }^{22}$

Professor Milton Diamond, Director of the John A Burns School of Medicine, University of Hawaii, has probably done more to research the intricacies of sexual formation and identity than any other single person. In a recent paper, he explained the different fundamentals of transgender and transsexualism thus:

Unlike the majority of transsexuals that "feel they were born that way" many of those identifying themselves as transgendered or gender-bending or gender-blending persons are attracted to the concept of a constructed gender and see themselves and their lives as evidence of it. Eschewing any strict male-female dichotomy, transgendered persons instead reach for a wide range of admixtures of male and female restructured anatomies and manifest masculine and feminine life-styles. For those most unique in their display, to reflect the socially bizarre nature of their expression, the term "gender fucking" is used by outspoken transgenderists themselves and others as well. The term is not seen as pejorative but apt...

Transsexuals, who I believe are intersexed, have the body and genitals of one sex and the brain of the other making reconciliation of their sexual and gender identities problematic. They solve their problems of reconciling, their disparate sexual identity and gender identity, by saying, in essence, "Don't change my mind; change my body." ${ }^{23}$

\footnotetext{
${ }^{22}$ Ibid $15-18$.

${ }^{23}$ Milton Diamond, 'Sex and Gender: Same or Different?' (2000) 10(1) Feminism \& Psychology 46.
} 
The Family Court of Australia in $\operatorname{Re} \operatorname{Kevin}^{24}$ heard detailed evidence from numerous international and domestic medical experts on the transsexual condition. His Honour Chisholm $\mathbf{J}$ came to the conclusion that the former narrow definition of "sex" established by Corbett $v$ Corbett ${ }^{25}$ thirty years earlier requiring congruency of all three of genitals, gonads and chromosomes, was no longer valid. Finding that the phenomenon of "brain sex" was a biological fact, he said:

In my view, the expert evidence in this case affirms that brain development is (at least) an important determinant of a person's sense of being a man or a woman ${ }^{26}$

... I see no reason why I should not accept the proposition, on the balance of probabilities, for the purpose of this case ${ }^{27} \ldots$

In my view, the evidence about the experience of transsexuals, and the strength and persistence of their feelings, fits well with the view that "transsexuals have a sexual brain development contrary to their other sex characteristics such as the nature of their chromosomes, gonads, and genitalia". ${ }^{28}$

I am satisfied that the evidence now is inconsistent with the distinction formerly drawn between biological factors, meaning genitals, chromosomes and gonads, and merely "psychological factors", and on this basis distinguishing between cases of intersex (incongruities among biological factors) and transsexualism (incongruities between biology and psychology) ${ }^{29} \ldots$

In my view the evidence demonstrates (at least on the balance of probabilities), that the characteristics of transsexuals are as much "biological" as those of people now thought of as inter-sex. The difference is essentially that we can readily observe or identify the genitals, chromosomes and gonads, but at present we are unable to detect or precisely identify the equally "biological" characteristics of the brain that are present in transsexuals. $^{30}$

Chisholm $\mathrm{J}$ held that the factors to be considered in determining a person's sex included, but were not limited to, the sex of the gonads, genitals, and chromosomes; any hormonal and surgical rehabilitative treatment the person had undergone; the person's perception of their sexual identity (a manifestation of brain sex); and the perception of others towards them. ${ }^{31}$

\footnotetext{
${ }^{24}$ Re Kevin [2001] FamCA 1074.

${ }^{25}$ Corbett v Corbett (otherwise Ashley) [1971] 83.

${ }^{26}$ Re Kevin [2001] FamCA 1074, [247].

${ }^{27}$ Ibid [248].

${ }^{28}$ Ibid [269].

${ }^{29}$ Ibid [270].

${ }^{30}$ Ibid [272].

${ }^{31}$ Ibid [329].
} 
Following a long line of precedents in Australia, he further held that, postoperatively, a person treated for transsexualism is a member of their reassigned sex. ${ }^{32}$

In his response to the debate on the Marriage Amendment Bill 2002 in the Federal Parliament, Senator Brian Greig ${ }^{33}$ referred to the text of Chisholm J's judgment above, commenting that:

...[T]he traditional understanding that transsexuals are biologically of one sex but psychologically of another, is mistaken. In fact, as the judgment stated, the argument is that transsexuals are as much biologically intersex as... other intersex cases are... ${ }^{34}$

The Full Court of the Family Court upheld the decision on appeal ${ }^{35}$ and, further, by means of what seemed to be, with the utmost respect to the Full Court, a rather circuitous discourse on the evidence and cases, affirmed the position in Australian law that transsexualism is, indeed, an intersex condition and established that people with transsexualism should not be treated differently to others with intersexed conditions. During the appeal proceedings, the Chief Justice, referring to the decision in $W v W,^{36}$ an intersex marriage case in the United Kingdom, pressed counsel for the Attorney-General as to what the Attorney-General's position might be

...if the Full Court were to accept the argument that brain sex was a biological characteristic, and upon this basis, ...effectively convert [the appeal] case into an intersex case, to which the principles adopted in [the $W$ $v W]$ decision, if correct, would apply... ${ }^{37}$

The Full Court disapproved of the first instance decision of Bell $\mathrm{J}$ in $C$ and $D^{38}$ that incorrectly relied on Corbett to hold a person who was born with both male and female physical characteristics could not marry. ${ }^{39} 40$ Approving the reasoning in $W v$ $W$ instead, the Full Court said:

\footnotetext{
${ }^{32}$ Ibid.

${ }^{33}$ Senator for Western Australia (Australian Democrats).

${ }^{34}$ Parliament of Australia, Hansard, Senate, 19 August 2002, in Australian Democrat Speeches, Available on-line at: 〈http://www.democrats.org.au/speeches/?speech_id=966\&display=1 >

35 Attorney-General of the Commonwealth $v$ Kevin and Jennifer and the Human Rights and Equal Opportunity Commission [2003] FamCA 94.

${ }^{36} W v W$ [2001] 2 WLR 673 before Charles J in the Family Division of the High Court of Justice. It was held that the test devised in Corbett does not apply to people with physical intersex conditions and they can marry in their chosen sex.

${ }^{37}$ Kevin and Jennifer [2003] FamCA 94, [180].

${ }^{38}$ In the Marriage of $C$ and $D$ (falsely called $C$ ) (1970) FLC 90, 636.

${ }^{39}$ Kevin and Jennifer [2003] FamCA 94, [225].

${ }^{40}$ Mathews J, in $R v$ Harris and McGuiness (1988) 17 NSWLR 158 (CCA) also noted that $C$ and $D$ had been strongly criticised in that His Honour had purportedly followed Corbett when that decision had no bearing on the case at all.
} 
It seems to us that the important thing about this judgment is that it clearly recognises that intersex persons can, in effect, choose their sex and marry... The question immediately arises as to why this principle does not extend to transsexual people; particularly if, as Chisholm $\mathbf{J}$ found, brain sex is a relevant factor in determining the issue. If it does not do so, this leaves transsexual people as the only group within the community that can never marry, except to a person who is a member of what they regard as the same sex as themselves. This is, of course, the reality in the case of transsexual people who have had surgical gender re-assignment, who can no longer function as a member of the sex, the physical characteristics of which they formerly had... ${ }^{41}$

...[I]f there is substance in the view that brain sex is one of the most significant determinants of gender, then the distinction between intersex and transsexual persons becomes meaningless, and the view of Charles $\mathbf{J}$ persuasive. This is because an intersex person appears to be defined as someone with at least one sexual incongruity. If brain sex can give rise to such an incongruity then, legally, we think that there may be no difference between an intersex person and a transsexual person. ${ }^{42}$

...[T]he evidence for the existence of 'brain sex' was much stronger and was uncontroverted before Chisholm J. We therefore think that on the evidence before him, it was open for Chisholm $\mathrm{J}$ to accept, on the balance of probabilities, that transsexualism is biologically caused...

Once this is accepted, we think it difficult to distinguish this case from the intersex cases such as $\mathrm{W} v \mathrm{~W} . . .44$

The Re Kevin decision was quoted extensively in the matter of Kantaras $v$ Kantaras, ${ }^{45}$ in Florida, where Judge Gerard O'Brien, handing down that decision at first instance, described it as 'one of the most important cases on transsexualism to come on the scene of foreign jurisprudence' ${ }^{46}$ The court in Kantaras heard evidence from Professor Julie Greenberg, amongst others, who explained in some detail the processes of sexual differentiation that lead to a person being either male or female and the various intersex conditions (including transsexualism) that can result when the

\footnotetext{
${ }^{41}$ Kevin and Jennifer [2003] FamCA 94, [231].

${ }^{42}$ Ibid [235].

${ }^{43}$ Ibid [290], [326].

${ }^{44}$ Ibid [291].

${ }^{45}$ In Re: Michael J Kantaras v Linda Kantaras [2003] Case No. 98-5375CA.

511998DR005375xxxxWS, $6^{\text {th }}$ Circuit, Florida.

${ }^{46} \operatorname{Ibid} 673$.
} 
process travels 'a path less followed'. ${ }^{47}$ Although Kantaras has since been appealed and reversed, a further appeal is now being prepared.

The Spanish Court of Appeals, Social Services Division, adopted a very similar line of reasoning in the 2003 matter of Katia in Madrid. ${ }^{48}$ The appellant health authority was found liable for the principal costs of hormone treatment and surgery for a woman living with transsexualism in Madrid. There was no evidence of any disorder of sexual differentiation other than the person's innate sense of their femaleness and overwhelming desire for surgical rehabilitation of their phenotype. The Appeals Court, affirming the judgment below, considered public policy that provided such services to people with "intersex pathologies", but purported to exclude those with transsexualism from its gambit, as discriminatory, and against the European Convention on Human Rights. The Appeals Court, after considering medical evidence as to the nature of transsexualism, held that the applicant 'is profoundly affected with a pathological intersex condition and that the guidelines require that the sex reassignment surgery be paid by Social Security'. ${ }^{9}$

Most recently, in the United States again, an Amicus Curiae brief provided to the US Supreme Court ${ }^{50}$ by the Harry Benjamin International Gender Dysphoria Association (comprising the majority of the world's experts in the field of transsexualism) stated:

The present findings of somatostatin neuronal sex differences in the BSTc and its sex reversal in the transsexual brain clearly support the paradigm that in transsexuals sexual differentiation of the brain and genitals may go in opposite directions and point to a neurobiological basis of gender identity disorder.

[T]ranssexualism is a disorder of sexual differentiation, the process of becoming man or woman as we conventionally understand it. Like other people afflicted with errors in the process of sexual differentiation, intersex conditions, transsexual people need to be medically rehabilitated so that they can live normalized lives as men or women.

The only available, successful and appropriate treatment at present for severe gender dysphoria is gender reassignment treatments, i.e. psychiatric assessments followed by hormone treatment, the real life test and in suitable cases, sex reassignment surgery. This has been confirmed by all long term studies. ${ }^{51}$

\footnotetext{
${ }^{47}$ See also Greenberg's dissertation at the Symposium on Therapeutic Jurisprudence conducted by the Arizona Board of Regents, published as: Julia A Greenberg, 'Defining male and female: Intersexuality and the Collision between Law and Biology' (1999) 41 Arizona Law Review 265.

${ }^{48}$ Madrid Institute of Health (IMSALUD) v Katia [2003] Appeals Court Case (SSD) No.30.

${ }^{49}$ Ibid.

${ }^{50}$ De'Lonta (Stokes) v Angelone et al (2004) C.A. \#7:99-CV-00642.

${ }^{51}$ Ibid 12.
} 
Thus, transsexualism is now widely regarded as just another of the biological variations that occur in human sexual formation - an intersex condition. It is about being a particular sex, not doing it. It is also about recognising gender norms, not challenging them. As the Full Court of the Family Court established in the Re Kevin appeal, "transsexual people" should have the same rights as others born with intersex conditions to be regarded for all legal purposes as the men and women they know themselves to be. The Victorian Government, as a consequence of its decision to deny people with transsexualism access to the statutory discretion in s 43 of the Births, Deaths and Marriages Act 1996 (discussed below), and the stated specific purpose of the 2004 amendment, failed to grant us those same rights and clearly left open the aetiology question ${ }^{52}$ despite being presented with substantial evidence that acceptance of the biological basis leads to markedly better acceptance of people with transsexualism in the broader community, and a significant decrease in the incidence of acts of discrimination and violence against them. ${ }^{53}$

\section{A VeRY Victorian INEQUITY}

Throughout Australia, legislation establishing procedures for birth registration makes provision for the correction of errors on the Register. In Victoria, the relevant provisions are found in s 43 of the Births, Deaths \& Marriages Registration Act 1996 (Vic). These allow the Registrar an administrative discretion to correct details in the Registrar inter alia to 'bring an entry about a particular registrable event into conformity with the most reliable information available to the Registrar of the registrable event'. One of the errors that the legislation is specifically intended to address is that arising when an infant is born with an ambiguity in sexual formation and the attending physician or midwife makes a decision as to the assignment of legal sex which is later contra-indicated through subsequent medical investigation.

The present Victorian Registrar, however, has exercised this discretion in a manner that has not been followed by any other jurisdiction in Australia. In Victoria, reassignment of legal sex has occurred under the discretionary power even though the individual's phenotypic sex had been previously medically assigned by hormonal treatment and surgeries for long periods, even decades, and no similar medical reassignment had preceded the correction. This was a compassionate response in view of the fact that Victoria, unlike the other jurisdictions, had no provision to deal with transsexualism until the enactment of the 2004 amendment just a few short months ago; but no such justification exists now.

\footnotetext{
${ }^{52}$ In comparison, the UK Government issued a clear and unequivocal statement that transsexualism has a neurobiological basis and is not a mental disorder. Introduction to 'Government Policy Concerning Transsexual People', Available on-line at: 〈http://www.lcd.gov.uk/constitution/transsex/policy.htm> ${ }^{53}$ See, for example, Mikael Landen and Sune Innala, 'Attitudes Towards Transsexualism in a Swedish National Survey’ (2000) 29(4) Archives of Sexual Behavior 375.
} 
In other jurisdictions, such as New South Wales, the Registrar's discretion in this context is only used to correct a mistake in physical sex identification, not to provide redress for a medical wrong perpetrated 30 years beforehand. A person who has had a legal and medical assignment of their sex during childhood who, much later, arrives at the decision that assignment was wrong for them is in precisely the same circumstances as anyone else experiencing transsexualism. ${ }^{54}$ They should have to avail themselves of the same procedures and meet the same requirements to correct their legal sex as does anyone else in similar circumstances - relevant crosshormone therapy and reasonable surgical interventions. There are very clear intentions expressed in other Australian jurisdictions that the specific provisions relating to transsexualism apply equally to all who similarly seek reassignment of their legal sex. The South Australian Act, for example, provides that:

..."reassignment procedure " means a medical or surgical procedure (or a combination of such procedures) to alter the genitals and other sexual characteristics of a person, identified by birth certificate as male or female, so that the person will be identified as a person of the opposite sex and includes, in relation to a child, any such procedure (or combination of procedures) to correct or eliminate ambiguities in the child's sexual characteristics. $^{55}$

The Registrar disagreed that this was, indeed, the case and, on the basis of the Registrar's advice and the insistence of some intersex activists that transsexualism is not an intersex condition against all the evidence, ${ }^{56}$ the Victorian Government pursued a legislative path for "transsexual people" and endorsed the continued use of the administrative approach for "intersexed" applicants. In so doing, the Victorian Government failed to comprehend the importance of the Full Court of the Family Court's enjoinder that people with transsexualism "should not be treated differently" and the considerable support received in that forum for the position that transsexualism has a biological basis and is hence to be regarded as another of the many different variations in human sexual formation - an intersex condition rather than a deluded deviance.

The Attorney-General told the Parliament, during the Second Reading Speech for the Bill to amend the Act, that:

\footnotetext{
${ }^{54}$ While no diagnostic tool for transsexualism exists, reliance continues to be placed on psychiatric analysis that differentially diagnoses transsexualism from contra-indicating conditions such as schizophrenia and transvestism. The American Diagnostic and Statistical Manual adopts a general terminology, Gender Identity Disorder, which it subdivides between the "Specific" adult manifestation, code 302.60, and "Other", code 302.85 which includes those with other intersex conditions including Androgen Insensitivity Syndrome (AIS) and Congenital Adrenal Hyperplasia (CAH).

${ }_{55}^{5}$ Sexual Reassignment Act 1988 (SA) s 3.

${ }^{56} \mathrm{See}$, for example, the emotive and legally flawed comments on the website of the Androgen Insensitivity Support Group Australia <http://home.vicnet.net.au/ aissg/transgender_and_intersex.htm> and the discussion at <http://eminism.org/interchange/2004/20040429-intersexandrogyn.html> and compare with <http://www.intersexualite.org/F-PositionsOfficielles.html>
} 
I note that the process of application to the registrar set out in the bill is not intended to apply to people with intersex conditions as these matters are already dealt with under the act. The act currently provides that where there has been a mistake at the time of entering details in the register, the Registrar of Births, Deaths, and Marriages may correct the register upon presentation of proof that such a mistake had been made. This provision is currently used to correct the birth records of intersex people. The bill will not alter this position. ${ }^{57}$

It seems that the rhetoric of these same radical intersex activists blinded both the Registrar and the Attorney-General to the fact that the hormonal and surgical assignment of an infant is a quite deliberate act taken on the basis of the best medical evidence then available. ${ }^{58}$ That it turns out to have been an incorrect assignment when the individual is an adolescent, or even an adult, and articulates what their neurological development instructs them is their sex, places the individual in precisely the same circumstances as anyone else who was incorrectly assigned to a particular sex as a child on the basis of the best evidence. It is a great tragedy that the paranoia of those intersex activists about being seen in the same medical basket as people with transsexualism was so intense that they failed to grasp the opportunity to seek their community's inclusion in the legislation and ensure it also contained a statutory requirement that all surgeries on intersexed infants be delayed until at least such time as the individual is able to give informed consent to the standard laid down in Gillick ${ }^{59}$ and adopted in Marion's Case. ${ }^{60}$

In my view, it is clear the Registrar is ultra vires the Act in these circumstances and the exercise of the discretion is therefore a misapplication of the power. If the position taken is held to be within the discretion provided by s 43 , however, then the amending legislation itself has enshrined a further discrimination against the most vulnerable minority in the Victorian community ${ }^{61}$ on the basis of their actual or perceived "sex" and "impairment". 62

\footnotetext{
${ }^{57}$ Births, Deaths \& Marriages (Amendment) Act, Hansard, Victorian Legislative Assembly 2004-04-22, 789

${ }^{58}$ This in no way justifies such procedures in infants in the absence of a true medical emergency and the author strongly supports the right of all people born with intersex conditions to exercise their rights to choose their sex and give their informed consent to any medical procedures necessary to support that choice.

${ }^{59}$ Gillick $v$ West Norfolk and Wisbech Area Health Authority [1986] AC 112.

${ }^{60}$ Secretary, Department of Health and Community Services v JWB \& Anor (Marion's case) (1992) 175 CLR 218.

${ }^{61}$ Victorian Gay \& Lesbian Rights Lobby, 'Enough is Enough: A Report on Discrimination and Abuse Experienced by Lesbians, Gay men, Bisexuals and Transgender People in Victoria' (2000).

${ }^{62}$ Equal Opportunity Act 1995 (Vic) s 6 provides that (b) "impairment" and (k) "sex" are attributes on the basis of which discrimination is prohibited in, inter alia, the provision of goods and services.
} 


\section{No Comparison in the LaW for the AGed, INFIRM OR VERY YOUNG}

In the Torah (comprising the first five books of the Hebrew bible) it is written that: 'Justice, justice shall you pursue'. ${ }^{63}$ Many scholars have questioned why the command repeats the word "tzedek" or "justice". The Talmud proposes that "the first mention of justice refers to a decision based on strict law; the second, to a compromise'. ${ }^{64}$ This is a two-fold understanding of justice recognising that sometimes, depending on the details of the context, the literal word of the commandment must be violated in order to preserve its spirit. In a similar vein, 'compassion fulfills the law of Christ'. ${ }^{65}$ Unfortunately, the spirit of compromise and compassion was largely conspicuous by its absence from the legislation amending the Births, Deaths and Marriages Registration Act 1996. his is certainly the case for those few people who, despite having been diagnosed with transsexualism and evinced an overwhelming desire to rehabilitate their phenotypic sex, are unable to do so because of contra-indicating medical conditions, especially those relating to the age of the applicant.

The plight of some older men and women living with transsexualism comes readily to mind here. Having finally reconciled their own inner fears, misgivings and internalised prejudices sufficiently to commence the arduous journey of transition, they discover, to their abject dismay, that they have health issues which preclude them from undergoing the more radical surgical procedures involved. Are they then to be left to die as they were born, legally assigned to the wrong sex? Similarly, what of the young diabetes sufferer or person with chronic nephritis who, simply by reason of their medical disability, is precluded from the benefit of this "human rights" initiative?

What is perhaps even less rationally considered is the circumstance a young adolescent with transsexualism is placed in by this omission. He or she is denied the peace of mind, safety and privacy of an appropriately corrected birth certificate because, first, surgery for transsexualism is deemed medically inappropriate until age 18 years and, secondly, because Victoria specifically legislated to deny this right to minors. This was precisely the case in the matter of Re Alex ${ }^{66}$ where the former Chief Justice of the Family Court of Australia was highly critical of the failure of the states and territories to grasp the welfare ramifications for children and deal with them. ${ }^{67}$ His Honour said:

...[A] young person such as Alex, on the evidence, would not be eligible for surgical intervention until at least the age of 18 years. Thus, for the

\footnotetext{
${ }^{63}$ Deuteronomy 16:20.

${ }^{64}$ Sanhedrin $32 \mathrm{~b}$.

65 The Holy Bible; Galatians 6:2.

${ }^{66}$ Re Alex: Hormonal Treatment for Gender Identity Dysphoria [2004] FamCA 297.

${ }^{67}$ This was particularly so in the case of the Victorian legislation which was still being considered in the Parliament and could easily have been amended to provide a lead for others to follow.
} 
many purposes for which a birth certificate is required (such as an application for a passport), a person such as Alex in those jurisdictions is required to produce a birth certificate that describes him as a female in circumstances where in all other respects he is living his life as a male... ${ }^{68}$

Reflecting upon the particular circumstances of this case leaves me anxious about the detrimental consequences that a young person such as Alex would suffer from having to present a birth certificate that is antithetical to his self-image... ${ }^{69}$

While His Honour appeared to be directing his criticism particularly to the Victorian proposals, it is a fact that legislation in most of the States in Australia excludes anyone under 18 years of age from correcting their details. This occurs either directly, as in Victoria ${ }^{70}$ and New South Wales ${ }^{71}$ where it is a statutory requirement the applicant be an adult, or indirectly, as in Queensland ${ }^{72}$ where although provision is made for children, surgery remains an absolute prerequisite for reassignment.

Prima facie, nothing appears to be possible to assist children under the existing provisions, but it is to be hoped for the sake of the others that medical professionals might heed the plea of the Victorian Parliamentary Secretary for Justice, Hon Jenny Mikakos, who said:

What I have learnt during the course of being involved in the development of this bill is that sex affirmation surgery is a complex matter, and it can encompass a range of surgical procedures. It will be the task of medical experts to determine when a person has had an adequate amount of surgery for the purposes of the bill. While the provision sets a legal standard, I am confident that the medical profession will use the scope available to assess individual patients... ${ }^{73}$

and thus temper their own interpretation of the law with some of the compassion sorely missing from the statute.

\footnotetext{
${ }^{68}$ Re Alex [2004] FamCA 297, [234]

${ }^{69}$ Ibid [236].

${ }^{70}$ Births, Deaths and Marriages Registration Act 1996 (Vic) s30A(1).

${ }^{71}$ Births, Deaths and Marriages Registration Act 1995 (NSW) s32B.

${ }^{72}$ Births, Deaths and Marriages Act 2003 (Qld) s 23.

${ }^{73}$ Second Reading Speech, Births, Deaths and Marriages Registration (Amendment) Bill 2004, Hansard

Victorian Legislative Council, 25 May 2004, 1067.
} 


\section{The Exclusion of Married Persons from Birth Certificate Reform and the Fallacies Underlying IT}

\section{A The "bogey" of same-sex marriage}

Recently, it seems, everyone is obsessed by the possibility that same-sex marriages may be legitimised in Australia as, indeed, they have been in a number of jurisdictions overseas. The prospect, however remote, that an activist federal judiciary may redefine "marriage" in terms that would allow the inclusion of gay couples, galvanised conservative forces in religion to demand, and in politics to provide, a legislated response guaranteeing the sanctity of this last bastion of heterosexism. There is no doubt that both sides in the current debate saw the decision in Re Kevin as the bridge by which the walls of the marriage institution might be breached.

Then Attorney-General, Daryl Williams, himself a Catholic and a staunch conservative, was certainly concerned that validation of the marriage between "Kevin" and "Jennifer" would give effect to a marriage between two women or, at the very least, would be seen to do so. ${ }^{74}$ During 1998 , while the couple were making inquiries about their plans to marry, they received an email ${ }^{75}$ from an officer in Williams' Department stating:

No matter what your partner's birth certificate will state, nor what surgery he/she has gender reassignment surgery does not change a person's biological sex, your partner remains of the female sex...

There would be enormous opposition to such a change from churches, etc. New South Wales faced enormous opposition to the changes it made in relation to the changed birth certificates, a change to the Marriage Act would raise even more controversy...

I am sorry we are unable to help you, but I am concerned that if you attempt to go ahead with the course of action you suggest you are leaving your partner open to criminal charges and the possibility of jail and I hope you will take this into consideration when making your decision... ${ }^{76}$

It was at this point that Kevin and Jennifer realised they would most definitely need a lawyer. Rachael Wallbank, herself a woman of transsexual background, agreed to take the matter on a pro bono basis and the rest is history.

\footnotetext{
${ }^{74}$ It should be noted that AG Williams did make an amount of funding available which gave the Court 'the advantage of some very detailed and scholarly presentations from both sides as well as evidence from some of the most distinguished medical experts in the world in this field' Re Kevin [2001] FamCA 1074, [3].

${ }^{75}$ Email addressed to "Jennifer", dated 2 October 1998.

${ }^{76}$ Ibid.
} 
According to the Australian Family Association, itself a front for the extreme right Catholic Lobby, the National Civic Council, the fundamental meaning of marriage is under attack. Taking a quantum leap over the existing boundaries of judicial reasoning, it suggests one way the gay lobby might achieve legal same-sex marriage

...would be to seek to expand the new common law test decided by the Full Bench of the Family Court in Attorney-General (Cth) $v$ Kevin and Jennifer as to whether a person is a man or a woman. This decision already incorporates psychological factors which may be given more weight than biological realities. The test set by the Court is so loose that it may be capable of being expanded to cover same sex marriages even where neither party is a transsexual. For example, it may be sufficient for one of a male homosexual couple to define himself as taking the part of the 'wife' or 'woman' in the relationship for a Court to recognise him as a 'woman' for the purpose of marriage. ${ }^{77}$

The Australian Family Association consequently still seeks the inclusion of biological definitions of "man" and "woman" in the Marriage Act 1961 (Cth). The collateral effect of this would be, as occurred under the rule in Corbett, the exclusion of all people with intersex conditions, including those with transsexualism, from the right to enter into a legal marriage.

Endeavour Forum's Babette Francis, an anti-feminist and another member of the extreme Catholic right, in an alarmingly candid statement of divine belief, recently wrote to me that:

I agree with you that gender assignment during infancy should not involve surgical mutilation, but I think gender assignment should be in conformity with chromosomes. While there may be many cases of gonad and genital anomalies, the chromosomes indicate what the brain sex is - or should be and this is the sex the infant should be assigned to.

I know there are some chromosomal abnormalities but the presence of a $\mathrm{Y}$ chromosome indicates male, and its absence indicates female. Surgical and hormonal treatments can follow when appropriate to match the chromosomal sex.

While I agree that most of those with "intersex" conditions may not be homosexual, the Kevin decision can be used by lobbyists for same-sex marriage. I do also dispute that there are actually "intersex" conditions. There are genital and gonadal abnormalities, but chromosomes indicate

\footnotetext{
${ }^{77}$ Richard Egan, 'Preserving Marriage in Australia' (2003) Family Update, Australian Family Association (WA) November-December 2003:1 〈http://www.family.org.au/update/2003/u20031101.html〉
} 
the sex. Genital and gonadal anomalies can be treated, chromosomes cannot be altered. ${ }^{78}$

In subsequent communications, I put it to Mrs Francis that, according to her position, a woman born with sex reversal syndrome, having naturally-formed female genitals and gonads, but XY chromosomes, would always be male. She agreed. I then asked her how she would determine the sex of someone with chimerism or mosaicism who is also an hermaphrodite. ${ }^{79}$ She procrastinated and attacked transsexualism on the basis there is no sexual incongruity (despite the overwhelming medical evidence to the contrary). Mrs Francis was also unable to answer the fact that an XXY woman (a man according to her view point) gave birth to a child. ${ }^{80}$ The fundamentalist Protestant churches hold very similar exclusionary views as to what determines sexual identity and likewise confuse it with sexual orientation. ${ }^{81}$

Distrust of judicial activism was also evident in the rush by Prime Minister Howard to "protect" the marriage institution from "contamination" and, in the process, manufacture another political wedge with which to keep the Opposition from power. His response, the Marriage Legislation Amendment Act 2004 (Cth), was strongly supported in the Parliament by conservative elements within both Government and Opposition and passed easily through both Houses. The position of religionists within the US Senate is equally clear. According to the Republican Policy Committee:

The pace of the gay marriage activists' campaign through the nation's courts is uncertain, but it is not at all certain that... legislation will stop determined activists and their judicial allies from pursuing this agendaonly a constitutional amendment will do that. ${ }^{82}$

\footnotetext{
${ }^{78}$ Perscomm, 24 June 2004.

${ }^{79}$ See, for example, Helen Pearson, 'Human Genetics: Dual Identities' (2002) Nature Online <http://www.nature.com/nsu/020429/020429-13.html> ; Jacques C. Giltay, Tibor Brunt, Frits A Beemer, Jan-Maarten Wit, Hans Kristian Ploos van Amstel, Peter L. Pearson, and Cisca Wijmenga1, 'Polymorphic Detection of a Parthogenetic Maternal and Double Paternal Contribution to a 46,XX/46,XY Hermaphrodite' (1998) 62 The American Journal of Human Genetics: 937 Available online at: 〈http://www.journals.uchicago.edu/cgi-bin/embpcgi.pl/cgi-bin/res-page.epl?objid=301796>

${ }^{80}$ The case of Eva Klobukowska, a Polish sprinter who was disqualified from the Olympics in 1967 because it was discovered that she had an XXY karyotype. See:

<http://news.ft.com/servlet/ContentServer?pagename=FT.com/StoryFT/FullStory\&c=StoryFT\&cid=108 7374099883>

${ }^{81}$ John Mark Ministries, a site owned by a Baptist Minister and school chaplain, has a full page dedicated to the same-sex debate and gives considerable prominence to the alleged likely interpretation of the Re Kevin decision in an activist court: 〈http://www.pastornet.net.au/jmm/articles/12830.htm> The site also lists the recent Victorian amendment to allow correction of birth certificates as a factor contributing to this fear of the eventual demise of heterosexual marriage. The Salt Shakers site lists groups like NARTH and Parakaleo Ministries under "transsexualism" but, to their credit and unlike similar others, they do respect Kevin's male identity in their website discussion of the case, available on-line at: <http://www.saltshakers.org.au/default.asp?s=saltshakers\&q=transsexual>

${ }^{82}$ Republican Policy Committee, 'The Threat to Marriage From the Courts' (2003) United States Senate, Washington, 29 July 2003, available on-line at 〈http://rpc.senate.gov/releases/2003/jd072903.pdf〉
} 
The Australian media did little to help from the outset and, for example, following the first instance decision in Re Kevin, we witnessed headlines in The Australian screaming "same-sex" in its description of the now validated marriage between Kevin and Jennifer. The Australian Press Council dismissed complaints that the material was 'factually wrong, maliciously misleading, intentionally sensationalist, offensive to the concerned couple, and distressing to other transsexuals' and considered it 'a brief, but balanced summary of the essential facts'. In its response to the complaints, The Australian pointed out that the "same-sex" view of the marriage was central to the Attorney-General's appeal. ${ }^{83}$ The author was the complainant in that matter and pointed out that it was central to the Court's decision that it was decidedly not a same-sex marriage. Even the radical left-wing competition, The Green Left Weekly, more usually noted for its incisive analysis of such issues, published the view that:

In challenging the notion that gender is anything other than predetermined from birth, transgender people challenge notions of fixed and unchanging gender and sexuality.

It's not a huge step to move from a transgender relationship being recognised in the eyes of the law to gay and lesbian relationships being given equal moral legitimacy. And that's something Darryl Williams and other social conservatives will work very hard to stop. ${ }^{84}$

The reality is, of course, that people living with transsexualism (unlike transgenders with whom they are often incorrectly categorised) actually reinforce the binary notion of gender. For people with transsexualism, homosexuality is the exception, rather than the rule, just as occurs in the rest of society, and the ultimate determination of sexual identity rests on far more complicated factors than chromosomes alone. But that fear of being seen to allow same-sex marriages and the electoral backlash flowing from it has led to some extraordinary assumptions and decisions impacting adversely on the understanding of transsexualism and the rights of those affected by it, especially those who have remained in a prior valid marriage following medically-induced changes to their phenotypic sex.

\section{B Legally confused or politically moribund?}

Section 5 of the Births, Deaths and Marriages Registration (Amendment) Act 2004 inserts a new Part 4A into the principal Act. Pursuant to this Part, s 30A(1) of the Act provides, inter alia, that an applicant seeking alteration of the record of their

\footnotetext{
${ }^{83}$ Adjudication No. 1164, (2002) Australian Press Council, Available on-line at: <http://www.presscouncil.org.au/pcsite/adj/1164.html>

${ }^{84}$ Sarah Stephen, 'And, Aint' i a woman?', Green Left Weekly, 13 February 2002 <http://www.greenleft.org.au/back/2002/480/480p6b.htm>
} 
birth registration must be unmarried. In its response to the Attorney-General's Discussion Paper preceding the proposed legislation, ${ }^{85}$ the Equal Opportunity Commission Victoria submitted, inter alia, that:

Discrimination against a person on the basis of their marital status is prohibited under both the Victorian Equal Opportunity Act and the Sex Discrimination Act 1984 (Cth). It is the Commission's view that precluding people who are married from accessing the proposed scheme would be contrary to the objectives of the Equal Opportunity Act.

The Commission further suggests that there are no clear legal reasons to prevent married persons of transsexual background from accessing the benefits of the proposed scheme. The 2003 Family Court case of the Attorney-General for the Commonwealth and "Kevin and Jennifer" and $\mathrm{Hu}$ man Rights and Equal Opportunity Commission (Intervener) has clarified that for the purpose of the validity of a marriage under Australian law, the issue of whether a person is a man or a woman is to be determined as of the date of the marriage. Therefore, the sex of the parties at any time after the date of the marriage is not relevant to the validity of the marriage. The implication of the decision in Re Kevin and Jennifer is that where one party to a marriage subsequently undergoes a process of sex affirmation, with the result that that party's affirmed sex is the same as their spouse's sex, the validity of the marriage will not be affected.

The Commission strongly suggests that the State legislature should not introduce provisions into the proposed scheme that prevent people of transsexual background who are married from being able to have their affirmed sex recorded on their birth certificates. The introduction of such discriminatory provisions would limit the effectiveness of the proposed reforms and cannot be justified, particularly in light of the legal position articulated above.

In his Second Reading Speech on the Bill for the Amendment on 11 May 2004, the Attorney-General, Hon Rob Hulls MP, made it very clear that the Government justified this patently discriminatory provision in the legislation on the basis of (i) consistency; ${ }^{86}$ and (ii) its fear of being seen to facilitate a same-sex marriage. During the debate, ${ }^{87} \mathrm{Mr}$ Hulls said:

\footnotetext{
${ }^{85}$ Equal Opportunity Commission Victoria, Submission in Response to the Attorney-General's Discus sion Paper: Changes to Birth Certificates for Transsexual People, (undated).

${ }^{86} \mathrm{Mr}$ Hulls neglected to point out that, being the very last of the States and Territories to act to rectify the neglect of human rights for people living with transsexualism, the second Brack's Government had the advantage of the guidance flowing from the Full Court of the Family Court's confirmation of the decision at first instance in Re Kevin and apparently ignored it for pragmatic, not legal reasons.

${ }^{87}$ Second Reading Speech: Births, Deaths and Marriages Registration (Amendment) Act 2004, Hansard, Victorian Legislative Assembly, 11 May 2004, 1107.
} 
I want to say a couple of things in relation to the unmarried aspect of the legislation. The first is that it is true this bill requires that a person be unmarried. This is consistent with the model in other states and territories...

The requirement for an applicant to be unmarried avoids the question of whether the person is in a same-sex marriage. An example would be if a person was born anatomically female, married a man and then later transitioned to being male - if that person were to remain married, the result would be prima facie a same-sex marriage. Given that marriage is a matter for the commonwealth government - which, I might say, has made its views on same-sex marriages very clear...

In relation to the likely illegality of the provision, vis-à-vis section 6 of the Sex Discrimination Act 1984 (Cth) ('the SDA') mooted by the Equal Opportunity Commission, the Attorney-General further stated:

...[W]e have advice that [inconsistency with the SDA] will not have ramifications in relation to that legislation.

If this legislation in Victoria did allow a person to be married before transitioning and changing their birth certificate it may be open to a legal challenge on the basis of inconsistency with the commonwealth Marriage Act. While here in Victoria we are committed as a government to ensuring that people in domestic partnerships are treated in the same way as married people, the inability of a married person to apply for a changed birth certificate under this legislation is based on commonwealth law, over which we in Victoria have no control.

With respect to the Attorney-General and those advising him, it is my view that enshrining such deliberate discrimination in legislation was nothing more nor less than a deliberate abrogation of the human rights of some members of a class of people for political, rather than any legal or medical science considerations. The Government decided to favour consistency with similar legislation existing in the other States and Territories, rather than consistency with the common law position enunciated in Re Kevin where the relevant ratio was distilled in the statement that 'the sex of a person for the purposes of marriage is their sex at the time of the marriage'. ${ }^{88}$ As was pointed out in a number of submissions to the Victorian Attorney-General, Chisholm J specifically considered the situation where a person who is already married completes sex affirmation treatment:

What would be the position if the marriage law were to recognise the reassignment? The marriage would I think still be valid: its validity would

\footnotetext{
${ }^{88}$ Re Kevin (validity of marriage of transsexual) [2001] Fam CA 1074, [330].
} 
be determined as at the date of the marriage, and I would not think it would become invalid by reason of the reassignment... ${ }^{89}$

The fact is that the assignment of transsexuals to one category or the other will inevitably mean that some of the person's characteristics will be those of the "other" sex. The law's task, in this area through the definition it gives to the everyday words "man" and "woman", is to reach a conclusion that is just, compassionate and sensible. ${ }^{90}$

Thus the Government has created a legal oxymoron where the sex of a person whose male phenotype has been rehabilitated to female by sex affirmation treatment is now regarded as a female under the marriage law, social security law, criminal law and administrative law, but is stuck with a male birth certificate that would, in effect, facilitate them marrying another female, a person of the same sex. Compassion and sense flew out the window when this became the law in Victoria.

\section{The ultimate discrimination and a legal remedy}

It seems not unreasonable to propose that denying both the existence of contemporaneous facts that determine the sex of a person and the person's consequent right to be recognised as a member of that sex under the laws of Victoria for all purposes, on the basis of the person's marital status, is the ultimate discrimination that anyone living with transsexualism has been subjected to in Victoria since the Full Court of the Supreme Court in $R v$ Cogley $^{91}$ first heralded our steady departure from the narrow essentialism of Corbett. It places those married individuals, and their spouses and children, in the invidious position of having to choose between their rights to marriage and family, and the right of the person with transsexualism to finally achieve legal status as the person they know themselves to be. In my view, this is not only morally wrong, but the offending provision is clearly ultra vires the SDA.

Section 6 of the SDA provides that:

(1) For the purposes of this Act, a person (in this subsection referred to as the discriminator) discriminates against another person (in this subsection referred to as the aggrieved person) on the ground of the marital status of the aggrieved person if, by reason of:

(a) the marital status of the aggrieved person; or

(b) a characteristic that appertains generally to persons of the marital status of the aggrieved person; or

(c) a characteristic that is generally imputed to persons of the marital status of the aggrieved person;

\footnotetext{
${ }^{89}$ Ibid.

${ }^{90}$ Ibid 305.

${ }^{91}$ [1989] VR 799.
} 
the discriminator treats the aggrieved person less favourably than, in circumstances that are the same or are not materially different, the discriminator treats or would treat a person of a different marital status.

(2) For the purposes of this Act, a person (the discriminator) discriminates against another person (the aggrieved person) on the ground of the marital status of the aggrieved person if the discriminator imposes, or proposes to impose, a condition, requirement or practice that has, or is likely to have, the effect of disadvantaging persons of the same marital status as the aggrieved person.

The section encompasses discrimination occurring in the supply of goods and services by virtue of s 2 , and the provision of birth registrations and certificates by government fall within its ambit. ${ }^{92}$

Under s 109 of the Australian Constitution, a law of a State or Territory which is inconsistent with a valid law of the Commonwealth, is invalid to the extent of the inconsistency. The Sex Discrimination Act 1984 was enacted by the Commonwealth under the external affairs power granted it by s 51(xxix) of the Australian Constitution and is a valid law of the Commonwealth. ${ }^{93}$ The object of the Act is to give effect to certain provisions of the Convention on the Elimination of All Forms of Discrimination Against Women ${ }^{94}$ and to eliminate, so far as is possible, discrimination against persons on the ground of...marital status. ${ }^{95}$ The provisions of s 30A of the Births, Deaths and Marriages Registration Act are therefore not only inconsistent with the SDA, but invalid in so far as they purport to deny a corrected Birth Certificate to an applicant who is married.

Finally, the Attorney-General's concerns of inconsistencies between the Victorian Act and the Marriage Act can be dismissed on the basis that the applicant's sex was correctly identified at the time of the marriage. An altered birth certificate subsequent to a prior valid marriage cannot affect the validity of the marriage and therefore the marriage can only be dissolved by divorce or the death of one of the parties.

\section{CONCLUSION}

The Victorian provisions to permit the correction of birth certificates following sex affirmation surgery are arguably the most forward-looking amongst the States and Territories. They are expeditious, clear and unambiguous. They avoid difficulties with definitions and provide the certainty in law that flows from the surgery re-

\footnotetext{
${ }^{92}$ IW v City of Perth \& Ors (1997) 191 CLR 1.

${ }^{93}$ Ansett Transport Industries (Operations) Pty Ltd $v$ Wardley (1980) 142 CLR 237, 242-3 (Barwick J).

${ }^{94}$ Sex Discrimination Act 1984 (Cth) s3(a).

${ }^{95} \mathrm{Ibid} \mathrm{s} 3(\mathrm{~b})$.
} 
quirement. Unfortunately, although the Victorian State Government, unlike the other States and Territories, had the advantage of being informed by the developments in the common law established by Chisholm $\mathrm{J}$ in Re Kevin at first instance and subsequently affirmed by the Full Court of the Family Court on appeal, the reforms they introduced do not reflect a concomitant level of wisdom and compassion.

For a particularly vulnerable few, those who are young or infirm and those who place the rights of spouse and children above their own, the new provisions actually enshrine the very discrimination they purport to remove by imposing untenable conditions based only in pragmatism and without medical or legal justification. This gives the knife of discrimination an especially vicious twist before it is withdrawn.

It seems inevitable that those aspects where the Government has opted for pragmatism instead of justice must now be tested in the courts. 